The Historical Journal, 63, 5 (2020), pp. 1079-1106 (C) The Author(s), 2020. Published by Cambridge University Press. This is an Open Access article, distributed under the terms of the Creative Commons Attribution licence (http://creativecommons.org/licenses/by/4.o/), which permits unrestricted re-use, distribution, and reproduction in any medium, provided the original work is properly cited.

doi:10.1017/Soo18246X1900o70o

\title{
GLOBAL SCIENCE, NATIONAL HORIZONS: SOUTH AFRICA IN DEEP TIME AND SPACE*
}

\author{
SAUL DUBOW \\ Cambridge University
}

A B S T R A C T. In his inaugural lecture, Saul Dubow, Smuts Professor of Commonwealth History at Cambridge University, discusses the modern history of science in South Africa in terms of 'deep time' and space, drawing links between developments in astronomy, palaeontology, and Antarctic research. He argues that Jan Smuts's synthetic discussion of South African science in 1925, followed by J. H. Hofmeyr's discussion of the 'South Africanization' of science in 1929, has parallels in postapartheid conceptions of scientific-led nation-building, for example in Thabo Mbeki's elaboration of the 'African Renaissance'. Yet, whereas the vision of science elaborated by Smuts was geared exclusively to white unity, Mbeki's Africanist vision of South African science was ostensibly more inclusive. The lecture concludes by considering South Africa as one of several middle order countries which have used national science and scientific patriotism to address experiences of colonialism and relations of inequality and to assert their influence in regional contexts.

In an easily overlooked passage in his best-selling autobiography, Long walk to freedom, Nelson Mandela recalls how, as a secondary school student, he witnessed a performance by the Xhosa praise poet Krune Mqhayi in which the stars were divided amongst the nations of the world. In the course of his recital, Mqhayi conceded the Milky Way to rapacious European colonizers and the constellations to various African polities. Then, at a critical moment,

Magdalene College, Cambridge, CB3 OAG shd28@cam.ac.uk

* Inaugural Lecture, Smuts Professor of Commonwealth History, Magdalene College, 28 November 2018. The author wishes to dedicate this lecture to the memory of his teacher and friend, Patrick Harries, who died suddenly in 2016. This article draws on material that will be published as The scientific imagination in South Africa, with William Beinart. The author is grateful to Professor Gary Gerstle who introduced his inaugural lecture, and to Magdalene College, which hosted it. Thanks as well to Paul Betts and James Secord for helpful comments. 
the imbongi dramatically lowered his voice, sank down on his knee, and claimed the gleaming Morning Star for the 'House of Xhosa'. A star-struck Mandela experienced intense pride. ${ }^{1}$

This formative episode is recalled by microbiologist and former president of South Africa's National Research Foundation, Khotso Mokhele, in his introduction to a lavishly illustrated book celebrating the success of SALT, the Southern African Large Telescope. Mokhele's purpose in retelling the story is to suggest that Mandela's engagement with the heavens at the start of the twentieth century might be read as a portent of 'how intense the relationship between the people of Africa and the heavens above could be', and as a means of stimulating 'questions that go to the root of our existence'. ${ }^{2}$

The implications of Mqhayi's striking division of the heavens between whites and blacks remains relevant today as many young South Africans question the premises of non-racialism and, for present purposes, the persistent view of 'western' science as a value-free, neutral activity, committed to the common good. Scepticism towards colonial knowledge and values has a long lineage. Mandela's own political formation describes an arc that saw him move away from a race-conscious 'Africanist' position in the 1940 s to become an advocate of multi-racialism the following decade and, after his release from prison, a committed and charismatic champion of non-racialism, human rights, and reconciliation. Even in the midst of the 'miracle' of political transition in the 199os (and well before the emergence of the angry twenty-first-century 'fallist movement'), a vocal constituency in the African National Congress (ANC) argued that the 'rainbow nation' of Mandela and Tutu was too much of a concession to the old order. Thabo Mbeki, Mandela's deputy, was one of these critics. In seeking to escape Mandela's long shadow, Mbeki expounded his own vision of an 'African Renaissance', an idea that combined a strongly developmentalist and technocratic approach with a commitment to the advance of indigenous knowledge.

This article explores unlikely parallels between today's scientific interests in deep time, associated with the country's post-apartheid entrance into the global community of nations, and earlier conceptions of South African science developed a century ago when racial segregation was being implemented in a systematic fashion. Notwithstanding major differences in assumptions and contexts, political leaders in both eras have had to grapple with matters of imperial, colonial, and indigenous knowledge. Understanding national science then and now raises intriguing conceptual questions about the production and diffusion of scientific knowledge in an internally divided, middle-order country, with claims to regional leadership. These questions are addressed towards the end of this article.

${ }^{1}$ Nelson Mandela, Long walk to freedom (London, 1994), pp. 38-40.

${ }^{2}$ Khotso Mokhele, 'Foreword', in D. Buckley et al., Africa's giant eye: building the Southern African large telescope (Cape Town, 2005), p. 5 . 
In an iconic speech marking the adoption of the new post-apartheid South African constitution in 1996, Mbeki proclaimed that he owed his being to the Khoi and the San, 'the blood of the Malay slaves who came from the East' and also to 'the migrants who left Europe to find a new home on our native land'. 'Being part of all these people, and in the knowledge that none dare contest that assertion', he declared: 'I am an African.' The speech was widely interpreted at the time as a profession of racial inclusivity. And to some extent it was. Yet, closer inspection of the text reveals nagging doubts. 'At times, and in fear', Mbeki confessed, 'I have wondered whether I should concede equal citizenship of our country to the leopard and the lion, the elephant and the springbok, the hyena, the black mamba and the pestilential mosquito.'3

As president of South Africa, such doubts came to the fore and Mbeki became reflexively Afro-centric. He convinced himself that HIV/AIDS was as much a blight on the dignity of African personhood as a matter of public health. Western pharma companies were wilfully exploiting the AIDS crisis in order to sell their drugs and experiment on Africans. Tragically, this drew Mbeki into the camp of AIDS denialism. He rejected a roll-out of anti-retroviral therapies in favour of indigenous solutions, including a fraudulent drug known as 'Virodene' which had no positive benefits other than to enrich its promoters. Hundreds of thousands of lives were unnecessarily sacrificed until the government was forced to change its policies (today, South Africa has the largest anti-retroviral roll-out programme in the world). Yet, in other respects, the modernizing Mbeki did great service to South Africa's involvement in global science.

In 1994, George Ellis, a distinguished cosmologist at the University of Cape Town and co-author of a book on Space-time with Stephen Hawking, prepared an important position paper on behalf of the Royal Society of South Africa. Along with its more demotic partner, the SA Association for the Advancement of Science, the Royal Society was a key civic institution in the tumultuous decade of reconstruction following the 1899-1902 South African War and culminating in the first new South Africa in 1910. Both organizations sought to detoxify British imperialism by presenting universal science in terms of the cool spirit of reason and reconciliation.

Now, as the miracle of the second new South Africa was being mapped, Ellis argued that twenty-first-century South Africa should prepare itself to become part of 'the global community'. He considered it unlikely that the country would become a 'great power' during the next century on account 'of

3 Thabo Mbeki, 'Statement on behalf of the ANC on the occasion of the adoption by the Constitutional Assembly of "The Republic of South Africa Constitution Bill 1996", Cape Town, 1996/o5/o8', <www.mbeki.org/2016/o6/o6/statement-on-behalf-of-the-anc-on-theoccasion-of-the-adoption-by-the-constitutional-assembly-of-the-republic-of-south-africa-constitution-bill-1996-cape-town-19960508/>. 
limited human and natural resources'. It would instead have to 'find an appropriate niche where its resources can be maximised through cooperation'. This would entail taking advantage of South Africa's position on the African continent and in the southern hemisphere. 4

Two years later, the government published a White paper, Preparing for the twenty-first century. This policy document maintained that science was about more than satisfying utilitarian objectives: we should not be 'a second-class nation, chained forever to the treadmill of feeding and clothing ourselves'.5 Big science was given a significant boost, especially the triptych of astronomy, palaeoanthropology, and Antarctic research. All three southern hemispheric spheres of activity sought to explore frontiers of knowledge within the frame of deep time and space.

\section{I I}

Astronomy has the distinction of being the first scientific discipline to gain institutional backing. This was by virtue of the creation of the Royal Observatory, established at the Cape in 1820 , by the British Admiralty. Thomas Maclear, among the most influential of Her Majesty's Astronomers at the Cape of Good Hope, arrived in 1834 and for more than thirty-five years laboured to embed astronomy in Cape scientific and civic life. One of Maclear's great projects was the construction of a meridian arc. This had important theoretical implications but it was also linked to achieving important practical aims such as navigation, measurement, and mapping. By the end of the century, and in the hands of David Gill, tracing the 3 oth degree Arc of the Meridian northwards through Africa became the celestial equivalent of Cecil John Rhodes's terrestial fantasy of a railway linking Britain's imperial domain from the Cape to Cairo.

There was also a larger scientific problem to be resolved, going back to the

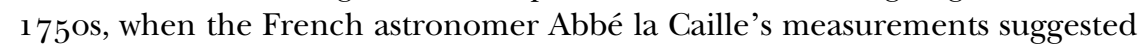
that the southern hemisphere was more flattened at the pole than the north. This implied, counter-intuitively, that the earth was shaped a bit like a pear. Over many years of laborious mountain climbing, lugging heavy, precision equipment, Maclear established that la Caille's calculations were indeed soundly based. His minor - but forgivable-error was not to have taken into account the micro-gravitational effects of the Cape's mountain masses on his plumb line. It is a long and captivating story, involving George Everest, amongst others: happily, it ends up vindicating la Caille's technical abilities and Newtonian physics too. ${ }^{6}$

4 George Ellis, Science research policy in South Africa: a discussion document for the Royal Society of South Africa, May 28, 1994 (Cape Town, 1994), pp. 13-14.

5 P. A. Whitelock, 'Optical astronomy in post-apartheid South Africa: 1994 to 2004', in A. Heck, ed., Organizations and strategies in astronomy, v (Dordrecht, 2004), pp. 40-1.

${ }^{6}$ Ian Stewart Glass, Nicolas-Louis De La Caille, astronomer and geodesist (Oxford, 2012). 
Also in 1834, the renowned British scientist John Herschel arrived at the Cape with his family. Herschel constructed his own private telescope in the garden of his suburban estate. With the help of his wife, Margaret, the Herschels spent long nights sweeping the skies in order to catalogue the star clusters, nebulae, and double stars of the southern hemisphere. Liberalminded and independent of means, Herschel became a key figure in the Cape's emerging scientific community. He worked closely with Maclear and together they observed the appearance of Halley's comet in 1835 . The following year, they entertained Charles Darwin when the Beagle docked in Simonstown. Darwin was a great admirer of Herschel and, although not overly impressed with what he saw at the Cape, recorded in his Beagle diary that the Cape was one of those colonial 'fragments of the civilized world' in which 'little embryo Englands are hatching'. 7

This embryo was not merely a facsimile of provincial England for it was already in the process of being coloured by local discoveries and priorities. John Herschel was fascinated by the Cape's unique botanical riches, planting his garden with indigenous fynbos bulbs and drawing pleasing landscapes and mountain views with the aid of a camera lucida. He played a leading role in devising a state-funded educational system that was independent of church oversight and geared to the acquisition of secular and scientific knowledge. Moreover, the Herschels and Maclears were critical of British imperial war-making on the Cape frontier. Margaret Herschel identified her husband as being on the 'side which humanity \& justice dictate, \& which is guarded by the mournful minority at the Cape'. ${ }^{8}$

After Maclear's retirement in 1870 , astronomy was consolidated through the energetic activities of David Gill who directed the Cape Observatory from 1870 to 1907. In the twentieth century, new observatories were established in the Transvaal and Orange Free State. The main rival to the Cape facility was the British-run Radcliffe Observatory, transplanted from Oxford University to Pretoria to take advantage of clear southern skies, and commissioned in 1948. American and European observatories also established 'viewing platforms' from which to survey the heavens of the southern hemisphere. Greater national consolidation was achieved with the creation, in 1973, of the South African Astronomical Association's observatory at Sutherland, and the repurposing of a 26 metre radio astronomy device at Hartebeesthoek which had been used by NASA to track spacecraft from 1961.9

7 R. D. Keynes, Charles Darwin's Beagle diary (Cambridge, 2001), p. 424.

${ }^{8}$ S. Ruskin, John Herschel's Cape voyage: private science, public imagination and the ambitions of empire (Aldershot, 2004), pp. 56, 54-5. On colonial botany and indigenous African knowledge, see Elizabeth Green Musselman, 'Plant knowledge at the Cape: a study in African and European collaboration', International Journal of African Historical Studies, 36 (2003), pp. $367-92$.

9 S. Dubow, '200 years of astronomy in South Africa: from the Royal Observatory to the "Big Bang”" of the Square Kilometre Array', Journal of Southern African Studies, 45 (2019), pp. 663-87. 
The end of apartheid offered new opportunities to position astronomy as a progressive, enlightened project. After years of political isolation, there was now a real prospect of re-entering the global community of knowledge. South Africa became the first and only country in the world to decommission its nuclear arsenal and soon the swords of 'big' science were being turned into ploughshares. Bernie Fanaroff, a Cambridge-trained astronomer who gained an international reputation in the $197 \mathrm{os}$ for his work on the classification of radio galaxies, gave up scientific research to spend the struggle years working for a trade union. In 1994, he joined the Mandela government and became closely involved in the MeerKAT radio astronomy project. He was followed a year later by Rob Adam, a physicist who had spent ten years in prison on account of his ANC activities. Fanaroff and Adam both served as directors and key protagonists of the hugely ambitious Square Kilometre Array (SKA) radio telescope project.

The SKA promises to be the world's biggest radio telescope. This international mega-project project, the total cost of which has recently been estimated at 1.8bn Euros, comprises a network of thousands of dishes and antennae concentrated in South Africa and Australia with its headquarters at Jodrell Bank outside Manchester. ${ }^{10}$ When completed, it may permit astronomers to catalogue radio sources with unprecedented speed and sensitivity. As well as providing a glimpse into the moment before stars and galaxies formed, searching for extra-terrestial cradles of life, and testing Einstein's General Theory of Relativity, the South African component of the SKA professes a strong developmentalist agenda: Africa, it is hoped, will be integrated into European and global science; a new generation of African scientists and technicians will receive advanced training; the infrastructure of very fast computing and big data will benefit the country; local communities will be able to take advantage of educational and employment opportunities.

Yet, as colleagues in a team lead by Cherryl Walker based at the University of Stellenbosch are showing, the SKA may prove problematic for those living in its environs. ${ }^{11}$ The Karoo is not a pristine area of semi-desert as the SKA likes to claim. It has been populated from the beginnings of human time and it has long been a site of contestation over land and resources. Locals seem to have been led to believe that Square Kilometre Array meant an area of around 1 square kilometre. In fact, the 200 dishes involved in the initial phase of the SKA are spread over some thirty large farms. The core site (along with the spiral arms that resemble a horizontal Catherine wheel) threatens to impose heavy restrictions on economic activity over a very extensive territory in the

${ }^{10}$ Anjana Ahuja, 'World's biggest telescope will chart the cosmic dawn', Financial Times, 18 Mar. 2019.

${ }^{11}$ For an overview of the issues, see C. Walker, D. Chinigò, and S.Dubow, 'Editorial', Journal of Southern African Studies Special Issue on Karoo Futures: Astronomy in Place and Space, 45 (2019), pp. 627-39. 
'advantage area'. Mobile phones and household devices emitting radiowaves threaten interference with the telescope's sensitive receptors. There have even been claims that commuter aviation from Cape Town to Johannesburg may have to be re-routed. A battle of resources based on bandwidth frequency thus pits the needs of global science against the interests of local communities, white as well as black. ${ }^{12}$

In Hawaii, first nation peoples have protested forcefully against the erection of a giant optical telescope on the sacred site of Mauna Kea in a striking instance of colliding global and indigenous cosmologies. ${ }^{13}$ In South Africa, by contrast, local and global tensions currently focus on modernity's distribution of material benefits. Assent has been secured by the SKA from indigenous spokespeople with questionable representative legitimacy. Promoters of the SKA, whose antennae are located in Australia and South Africa, have recruited the idea of first nation commonality to their cause. This is essayed in the hopeful idea of 'Shared Skies', the title of a travelling international exhibition featuring Australian and South African indigenous art; it is said to be stimulated by 'essentially identical views of the night sky to the peoples that have lived there for tens of thousands of years' and the attractive notion that the 'night sky is an increasingly scarce natural resource that belongs to and is shared by all humanity'. ${ }^{14}$

But what is the nature of this sharing? The region of the Karoo designated for the SKA coincides almost exactly with land previously occupied by |Xam Bushmen, whose mythology and folklore is replete with interpretations of the stars and heavenly bodies as narrated by $\|$ Kabbo to the nineteenth-century philologist, Wilhelm Bleek, and his co-worker Lucy Lloyd; it is part of an 'intimate cosmology' in the striking phrase of John Parkington et al. ${ }^{15}$

The descendants of the Xam hunterers and gatherers were systematically alienated from their lands by settler colonialism through the eighteenth and nineteenth centuries. Whereas modern scientific cosmology sees no direct relationship between humans and the universe - other than, say, in raising the possibility of extra-terrestial intelligent life - |Xam conceptions of the universe were intrinsically related to human life for the domains of landscape and sky were interconnected. Colonial dispossession and capitalist farming has eviscerated the physical and spiritual links between indigenous people and their ancestral lands; the SKA offers little by way of compensation to their descendants.

The SKA builds on the success of SALT, an 11 metre optical telescope (modelled on the Hobby-Ebberly telescope at the McDonald Observatory in Texas)

\footnotetext{
12 See e.g. 'SKA is ruining the Karoo's future', <http://savethekaroo.com/>; Tshegofatso Mathe, 'SKA bends the Jhb-Cpt Continuum', Mail and Guardian, 19 July 2019.

13 See e.g. M. Broder Van Dyke, 'Dozens arrested at protest over new telescope in Hawaii', Guardian, 19 July 2019.

14 'The shared sky concept', <www.skatelescope.org/shared-sky/>.

15 J. Parkington, D. Morris, and J. M. de Prada-Samper, 'Elusive identities: Karoo Xam descendants and the Square Kilometre Array', Journal of Southern African Studies, 45 (2019), p. 733.
} 


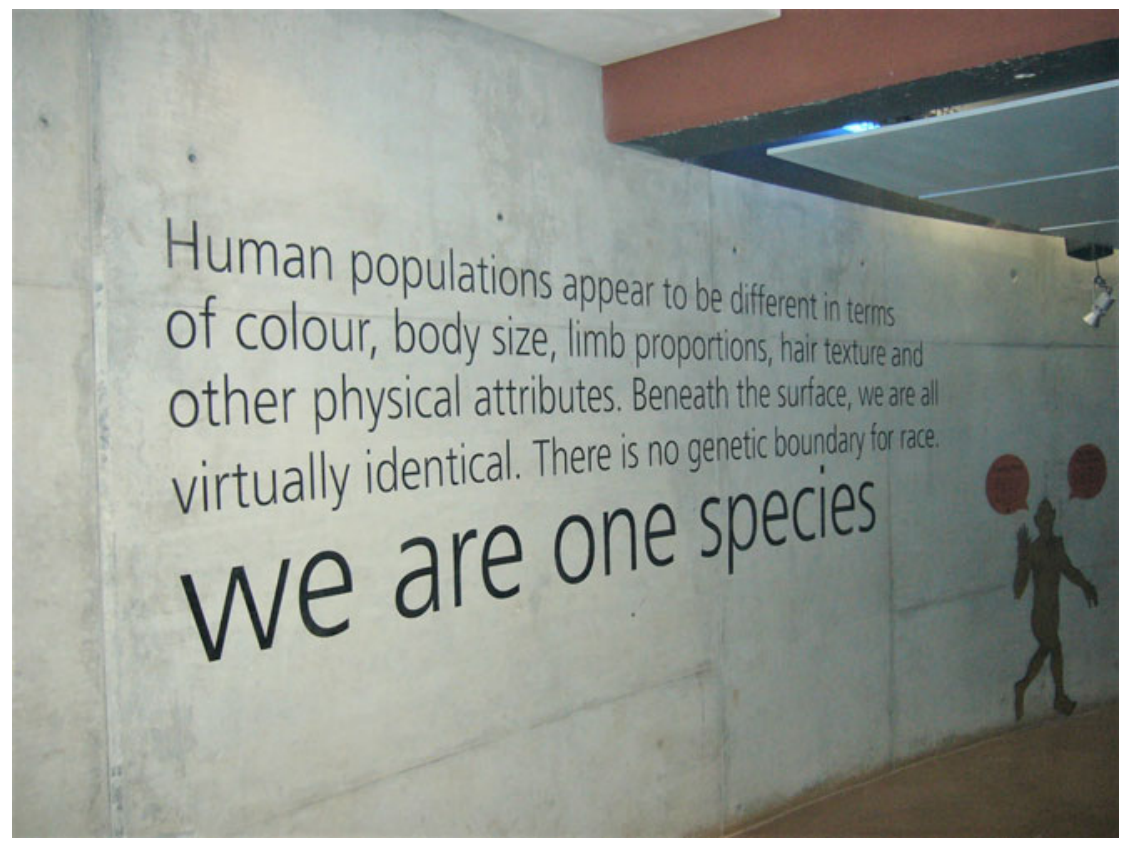

Fig. 1. Entrance to Maropeng Visitor Centre, Cradle of Humankind World Heritage site.

which stands proudly on a plateau above the town of Sutherland. On the occasion of the telescope's inauguration in 2005 , President Thabo Mbeki predicted that this 'giant eye in the Karoo [will] tell us as yet unknown and exciting things about ourselves'. He proclaimed that the 'multi-national' venture would 'provide all humanity with the largest and most modern single optical-infrared telescope in the southern hemisphere, while enabling our country and continent to remain among the front ranks of those involved in astronomy'.

Then, in an interesting leap of the imagination, Mbeki proceeded to draw a direct connection between the cosmic potential of SALT and a new 'Cradle of Humankind Interpretation Centre' to the west of Johannesburg. Known as 'Maropeng' - Setswana for 'the place where we once lived' - the visitor centre sits in the midst of a 'vast palaeontological storehouse' which has been declared a UNESCO World Heritage Site (Figure 1). For Mbeki, this was living proof that 'our country is the Cradle of Humanity'; for South Africans, as human beings, it was appropriate 'to continue the search for the origins of the infinite beginnings of the universe...in the very geographic space that gave birth to homo sapiens'. ${ }^{16}$

16 'Speech of the president of South Africa, Thabo Mbeki, at the official inauguration ceremony of the Southern Africa Large Telescope (SALT): Sutherland, Northern Cape', 10 Nov, 2005, at <www.polity.org.za/article/mbeki-inauguration-ceremony-of-southern-africa-large- 
The Cradle of Humankind has been yielding hugely important fossils dating back some $3.5 \mathrm{~m}$ years. In 1936, an adult Australopithecus cranium, along with baboon skulls and endocrinal casts, was found by an inquisitive schoolboy at limeworks in the Sterkfontein caves, a rich excavation site within the Cradle. These finds were handed to the venerable palaeontologist, Robert Broom, who identified the evolutionary significance of the cranium by showing its resemblance to Raymond Dart's iconic Australopithecus, described a decade earlier. In 1938, Broom identified Paranthropus, a fossil skull found at Kromdraai, as a more robust variant in the australopithecine line. ${ }^{17}$ Both finds provided confirmatory evidence of South Africa's importance in the exciting story of human evolution.

Very recent discoveries at the Cradle, like the $2 \mathrm{~m}$ year old assemblage of Homo naledi bones unearthed in 2013, have raised the prospect that this small-brained human-like species deliberately buried their dead in the difficult to access cave system. Lee Berger, the Indiana Jones of South African palaeoanthropology, who refers to his intrepid team of excavators as 'underground astronauts', makes the remarkable claim that naledi, who lived around 300,ooo years ago, might have been capable of symbolic behaviour and complex social organization. ${ }^{18}$ At the 2015 ceremony at Wits where Berger 'gave' Naledi to the world, an effusive Cyril Ramaphosa, now president of South Africa, predicted that Naledi would 'catch the imagination' of the world and inspire a retelling of the 'story of our own common ancestry'. Wits vice-chancellor Adam Habib stressed the discovery of naledi as a contribution to 'a common humanity'. ${ }^{19}$

Philip Tobias, grandee of South African palaeoanthropology, veteran antiapartheid intellectual, and praise-singer of the African Renaissance, was justifiably proud of the World Heritage Site - having personally done a great deal to bring it about. In a keynote address to a conference on the 'African RenaisScience' in 2002, Tobias captured the spirit of the moment by claiming that South African's Australopithicenes were the progenitor of all living humans; that 'Africa gave the world its first culture', and that Southern African hominids

telescope-101 1 2005-2005-1 1-10>; D. Buckley, 'Salt: "Gigantic African Eye”, Quest, 2 (2005), pp. 6-9.

17 W. E. Le Gros Clark, 'Significance of the Australopithecinae', Nature, 157 (1946), pp. 863-4; R. Broom and J. T. Robinson, 'Ape or man?', Nature, 166 (1950), pp. 843-4.

${ }^{18}$ Lee R. Berger et al., 'Homo naledi, a new species of the genus Homo from the Dinaledi Chamber, South Africa', eLife, 1o Sept. 2015; Ralph L. Holloway et al., 'Endocast morphology of Homo naledi from the Dinaledi Chamber, South Africa', PNAS, 115 (2018), pp. 5738-43; Paige Williams, 'Digging for glory', New Yorker, 27 June 2016; M. Greshko, 'Cave explorers find new fossils of mysterious human relative', National Geographic, 13 Sept. 2017; Jamie Shreeve, 'This face changes the human story. But how?', National Geographic, 10 Sept. 2015.

19 <www.wits.ac.za/homonaledi/> and <www.wits.ac.za/homonaledi/whats-new/news/ homo-naledi-our-new-human-relative.html. 
were 'not a southern African aberration, but a pan-African revelation'. ${ }^{20}$ Four years earlier, this polymath - and skilled wordsmith - addressed a government cabinet meeting with an inspiring idea: 'Africa is the birthplace of humanity. Instead of African Renaissance, you should be talking about African Naissance.' ${ }^{21}$

This message played well in post-apartheid's brief non-racial global moment. It was not always thus. The study of human origins in South Africa coincided with the elaboration of racial segregation in the first decades of the twentieth century. In 1925, Australopithecus africanus was announced to the world by the Wits palaeontologist and comparative anatomist, Raymond Dart, shortly after he succeeded in freeing the juvenile fossil skull from breccia blasted out of a limestone quarry in the northern Cape. According to Dart, Australopithecus vindicated Darwin's prediction in The descent of man that it was 'more probable that our early progenitors lived on the African continent than elsewhere'. For many years, Dart was derided for his audacity. Until the 195 os, metropolitan science took the view that modern humans were far more likely to have emerged in China or in Europe. One of Dart's strongest critics was Sir Arthur Keith, a president of the Royal Anthropological Institute and a leading eugenist, who was not well disposed to theories emanating from the colonial margins. Keith is strongly implicated in the famous Piltdown fossil forgery which gave rise to the view that early man was an Englishman who once roamed the Sussex Downs. Tobias, always a passionate defender of Dart, fingered Keith as a likely Piltdown conspirator, accusing him of pursuing two decades of 'vocal, vigorous, and authoritative rejection' of Dart. ${ }^{22}$

Dart was a charismatic, consummate performer, who was much given to speculation and guess-work. He was also a hyper-diffusionist, greatly influenced by his Australian compatriot, Grafton Elliot Smith. Throughout his working life, Dart invariably attributed Neolithic and iron-age cultural advance in southern Africa to direct influences emanating from the near or far east. When the Cambridge archaeologist, Gertrude Caton-Thompson, presented her findings in support of the indigenous origins of Great Zimbabwe at the joint meeting of the British and South African Associations of Science in 1929, Dart stormed out of the lecture room in protest. Dart and his colleague, Robert Broom, were habitual 'splitters': palaeoanthropology or comparative anatomy was, for them, all about finding original ancestral 'types' or 'stocks'. They were thus disposed to stress difference over similarity. Freud's 'narcissim of

${ }^{20}$ S. Dubow, 'White South Africa and the South Africanisation of science', in P. Bonner et al., A search for origins: science, history, and South Africa's 'Cradle of Humankind' (Johannesburg, 2007), p. 9 .

${ }^{21}$ Christa Kuljian, Darwin's hunch: science, race and the search for human origins (Auckland Park, $2016)$, p. 236.

${ }^{22}$ P. V. Tobias, 'An appraisal of the case against Sir Arthur Keith', Current Anthropology, 33 (1992), p. 244 . 
small differences' could be the epitaph of more than one palaeoanthropologist from this generation.

Palaeoanthropology is a discipline where the object of discovery is uniquely identified with the discoverer. Ancestral lines of descent mirror academic links of patrimony and patronage. For all his achievements, Tobias never made a major fossil find discovery of his own and, instead, inherited Dart's australopithecine child specimen along with Dart's chair. Tobias's protection of the legacy of Raymond Dart has partly to be explained in psychological terms for Dart evidently became a substitute father to him. And yet father and son came to rather different conclusions about human differences: whereas Dart was fixated on the evolution of different kinds of humans, and assumed inequality to be innate, Tobias professed the unity of humankind and upheld egalitarian and anti-apartheid views. Tobias could never himself confront this contradiction.

\section{$\mathrm{V}$}

Jan Smuts, the South African statesman whose name is memorialized at Cambridge in the Smuts Memorial Fund and the title of my Chair, was also deeply concerned with the political dimensions of science. After losing prime ministerial office at the 1924 general election, Smuts spent a productive decade in political opposition developing his views on these matters and shaping his credentials as a Commonwealthman statesman. In his presidential address to the South African Association for the Advancement of Science in 1925 , Smuts made a remarkable effort to shift emphasis on the 'European continent', home of nineteenth-century science, to the southern hemisphere, so as to demonstrate how this might contribute 'to the sum total of scientific knowledge'. In order to effect this hemispheric reorientation, Smuts posited Africain particular, the Witwatersrand watershed of South Africa and the Rift Valley to the north - as marking a 'great "scientific divide" among the continents'. Smuts thought that it was along this east/west axis that scientific prospectors might find 'the most precious and richest veins of knowledge'. 23

Smuts was quick to recognize the significance of Australopithecus. He hastened to congratulate Dart on his recent 'epoch-making discovery', assuring him that it 'reflects lustre on all South Africa'. ${ }^{24}$ Without giving unequivocal support to Dart's claims, Smuts referenced Darwin in support of the view that Africa might prove to be the birthplace of man. Considered together with other recent fossil finds, he asked whether South Africa may yet 'become the Mecca of Human Palaeontology?'. ${ }^{25}$

Smuts did not infer that common origins meant commonality. On the contrary, Africa might not turn out to be the cradle of mankind so much as 'one

${ }^{23}$ J. C. Smuts, 'South Africa in science', South African Journal of Science, 22 (1925), pp. 3-4.

${ }^{24}$ R. A. Dart with D. Craig, Adventures with the missing link (London, 1959), pp. 36-7.

${ }^{25}$ Smuts, 'South Africa in science', pp. 17-18, 16. 
of the cradles' - a clear suggestion of Smuts's willingness to entertain multilinear theories of human evolutionary divergence. As he put it, 'Our Bushmen are nothing but living fossils whose "contemporaries" disappeared from Europe many thousands of years ago.' They were analogous to 'true "living fossils", like cycads, botanical survivors from the Jurrassic era. One of South Africa's distinct advantages as a field of scientific research was that, being thousands of years behind the times, evolutionary processes and biological problems could here 'be studied from life' ${ }^{26}$

In his 1925 address, Smuts accorded great significance to the new, but still controversial, theory of continental drift espoused by the German meteorologist and polar expert, Alfred Wegener, in a now famous lecture given in 1912. A decade later, the brilliant South African field geologist, Alexander Logie du Toit, began to put a distinctive new spin on the concept by modifying Wegener's focus on an original supercontinent known as Pangaea. Based on his detailed understanding of rock formation in the Karoo Supergroup system, his first-hand acquaintance of geological formations in Latin America and Australasia (which displayed strong affinities with the Karoo), as well as his acquired knowledge of palaeobotany and palaeontology, du Toit proposed the existence of two original supercontinents: Laurasia to the north and Gondwana to the south. He argued that the fracturing of Gondwanaland gave birth to the modern land masses of Africa, South America, India, and Australia. ${ }^{27}$

$\mathrm{Du}$ Toit lent vital support to the Wegener thesis in Our wandering continents (1937). While endorsing the still highly controversial theory of continental drift - which was strongly resisted by American geologists and only confirmed by geomagnetic evidence and the paradigm-shifting concept of plate tectonics in the $1960 s-d u$ Toit's effort to 'elaborate the architecture of the Globe' subtly modified Wegener's approach. ${ }^{28}$ This reorientation southwards was signalled by a motto inserted in the title page of Our wandering continents: 'Africa forms the Key'. ${ }^{29}$ Smuts's reading of du Toit's early work gave Africa a new global centrality - as signalled by du Toit's 1924 address on 'The contribution of South Africa to the principles of geology'.30 Africa could now be viewed as the

26 Ibid., p. 17 .

${ }^{27}$ T. W. Gevers, The life and work of Dr. Alex. L. du Toit (Johannesburg, [1949]). I have benefited, too, from reading a draft manuscript on du Toit by Suryakanthie Chetty.

${ }_{28}$ The story of American resistance to continental drift, and the rejection of much of du Toit's findings, is well told by N. Oreskes in The rejection of continental drift: theory and method in American earth science (New York, NY, 1999).

29 Alex L. du Toit, Our wandering continents: an hypothesis of continental drifting (Edinburgh, 1937). See also S. H. Haughton, Obituary notices of fellows of the Royal Society, 6 (1949), pp. $385-95$.

$3^{\circ}$ Alex du Toit, 'The contribution of South Africa to the principles of geology', South African Journal of Science, $21(1924)$, pp. $5^{2-78}$. In this wide-ranging talk to the South African Association of Science, du Toit set out his developing ideas on Gondwanaland and what he then called 'continental disruption'. 
'mother-continent' from which South America, Australasia, and India had 'calved off'. ${ }^{11}$ By placing South Africa at the centre of the 'great divide', Smuts was thus making a case for the country's singularity as well as its universal significance. Smuts did not, however, dwell on the importance of India, from which the term 'Gondwanaland' is derived. By contrast, du Toit was deeply interested in India, visiting the subcontinent in $1937-8$. He interacted on terms of respectful equality with leading Indian scientists like renowned palaeobotanist Birbal Sahni, discoverer of fossil glossopteris plant, as well as geologist L. Rama Rao, an expert on India's cretaceous period. ${ }^{2}$

As Pratik Chakrabarti points out, Gondwanaland is derived from the ancient Gonds; it was deployed by British colonial ethnographers and scientists who were entranced by the region's volcanic landscape, its fossils, and its tribal inhabitants. In Chakrabarti's view, the idea of Gondwana was used to link the evolution of landscape and the peopling of India in ways that resonated with colonial ethnology, geology, and Christian faith.33

It was Smuts's expertise in botany (he was an acknowledged authority on veld grasses) that disposed him to accept the Wegener-du Toit thesis. Smuts dismissed as a 'European fallacy' the view that South African plant distribution was the consequence of southward migration of the temperate flora of Europe. Drawing instead on Charles Darwin's theory, in a letter to Hooker, that the development of higher plant forms may have taken place in an ancient ' isolated continent or large island, perhaps near the S. Pole', Smuts suggested that the unique Cape floral kingdom as well as the country's tropical and sub-tropical flowering plants most likely derived from Gondwanaland.34 In effect, Smuts was proposing for South Africa what Australian scientists were hypothesizing at much the same time: the existence of 'great south lands' in Permian times linking Australasia to Antarctica. In both cases, this interpretation helped to challenge deep-seated feelings of colonial isolation and inferiority based on southern hemispheric marginality. 35

Botany was also Smuts's way into meterology and climate, fields that to his regret had so far elicited 'only a mild scientific interest'. In 1932 ('Climate and man in Africa'), Smuts would explain climate as the single greatest factor responsible for racial divergence. $3^{6}$ Smuts was also much concerned about climate change in respect of the 'progressive dessication of the land' as highlighted by

31 Smuts, 'South Africa in science', p. 4 .

$3^{2}$ See A. L. du Toit's personal papers, BC722, University of Cape Town, boxes B3.4, F2.2, and $\mathrm{F}_{2} .8$.

33 Pratik Chakrabarti, 'Gondwanaland and the politics of deep past', Past and Present, 242 (2019), pp. 119-53.

34 Smuts, 'South Africa in science', pp. 7-8; cf. C. Darwin to J. D. Hooker, 12 Aug. 1881 , Cambridge University Library (MS DAR 95: 524-7), <https://cudl.lib.cam.ac.uk/view/MSDAR-00095-00524/4>.

35 Tom Griffiths, Slicing the silence: voyaging to Antarctica (Sydney, 2007), pp. 69-82.

$3^{6}$ J. S. Smuts, 'Climate and man in Africa', South African Journal of Science, 29 (1932), pp. $9^{8-1} 3^{1 .}$ 
the 1923 Drought Investigation Commission in South Africa. The dearth of scientific knowledge about the African climate, he argued, might be remedied by establishing meteorological observatories in the Antarctic so as to improve long-range weather forecasting. Smuts therefore proposed a joint AustralianSouth African Antarctic station to aid in climatic research. This would have the additional merit of reinforcing Commonwealth solidarity. 37

The title of Smuts's 1925 address, 'South Africa in science', was carefully chosen. He was concerned not only to detail the history of science as practised in South Africa but, more ambitiously, to demonstrate the country's significance in (i.e. for) universal science. By invoking deep geological time in respect of botanical and anthropological processes, Smuts was therefore suggesting that the deep past offered modern scientists unique research possibilities in addition to holding 'the key to stable and permanent future progress'. $3^{8}$ South Africa, in other words, was integral to modern science-just as science was vital to the country's future.

In 1929, the British Association returned to South Africa as guests of the South African Association for the Advancement of Science. A high-powered delegation, including 44 fellows of the Royal Society, were amongst the $5^{\text {oo visi- }}$ tors. Throughout, conspicuous efforts were made by the visitors and their hosts to reinforce the theme of dominion parity and respect for national feelings. Jan Hofmeyr, Smuts's political deputy and a noted liberal-minded intellectual in his own right, was president of the South African Scientific Association in 1929. Hofmeyr was greatly concerned to highlight advances since the last visit of the British Association to South Africa in 1905 when, on his account, science remained dependent on overseas expatriates and so could be termed 'exotic'. Happily, science was now more mature and institutionally rooted. Hofmeyr referred to this generational change as the 'South Africanisation of Science'. He hastened to add that there was 'nothing narrow' about scientific South Africanism: indeed, to be so would be 'false to the spirit of Science'.39

For Hofmeyr, as for Smuts, science was a means to articulate an outwardlooking form of patriotism and ethnically inclusive white South Africanism. Their emphasis on the country's scientific potential might be seen as prefiguring what we would now term intellectual 'decolonialization' - albeit in a form that decentred Europe while reinforcing white Commonwealth leadership. The title of Hofmeyr's speech, 'Africa and science', nodded to Smuts and also gave expression to Smutsian hopes of white northern expansion by way of incipiently sub-imperial aspirations: having South Africanized science, the next objective, was to 'Africanise' it. $4^{\circ}$

37 Smuts, 'South Africa in science', p. 11.

$3^{8}$ Ibid., p. 19.

39 J. H. Hofmeyr, 'Africa and science', South African Journal of Science, 26 (1929), pp. 4, 6-7.

$4^{\circ}$ Ibid., p. 8. Hofmeyr's speech was given extensive press coverage in South Africa, and also in Britain. See e.g. the account in Times, 27 Mar. 1929. 
Hofmeyr duly presented South Africa to his British visitors as the 'Southern gateway' by which 'Science itself can most effectively be made to permeate Africa.' He highlighted the potential of medicine, economics, anthropology, palaeontology, and linguistics. These disciplines offered 'the richest opportunities to those who would investigate racial problems in the true Spirit of Science', and in discovering solutions, the 'clash of colour' might be averted. Africa could thus be seen as a 'great laboratory' wherein scientists might test 'diverse social and political theories as to the relations between white and coloured races', 'the solution of which will affect or determine the handling of similar problems throughout the world'. $4^{1}$

It was as a laboratory for race that South Africa marketed itself globally, not least in fields like educational sociology. One of the most enthusiastic responses came from the Carnegie Corporation of New York which, under the energetic leadership of Frederick Keppel, sponsored a major investigation into the problem of white poverty. The five-volume report, completed in 1932, was a landmark in South African social science. It was also important for thinking around the problem of race in the American South, serving in some respects as a progenitor for Gunnar Myrdal's Carnegie-funded American dilemma. In the 1920 and 1930s, American foundations such as Carnegie and PhelpsStokes, as well as its leading universities like Harvard, were brokering new intellectual relationships with colonial Africa, namely, offering their intellectual and financial resources, ostensibly without the imperial baggage.

For Smuts, international statesmanship, institution-building, and scientific advance were powerfully conjoined. He gave philosophical expression to this view in a treatise entitled Holism and evolution (1926) in which he ruminated on the organic and evolutionary links between the smallest elements of matter and the largest problems of the universe. These ideas formed the basis of his presidential address to the centenary meeting of the British Association in 1931 in which he recruited quantum theory and relativity to advance his idea that 'the nature of living things is determined, not by the nature of their parts, but by the nature of their organization'..$^{2}$

The philosophical and scientific rigour of holism has been much debated. At the 1929 scientific meeting of the British and South African Associations, Lancelot Hogben, then professor of zoology at the University of Cape Town, and soon to become a leading figure in left-wing anti-eugenist thinking, ridiculed Smuts's woolly metaphysics with a withering materialist refutation. J. S. Haldane, who sought to negotiate a philosophical course between vitalist and mechanist biological science, was more sympathetic to Smuts's holist philosophy at the Cape Town symposium and also in his 1927-8 Gifford lectures. Here, Haldane attributed to Smuts the valuable insight that 'the existence of

$4^{1}$ Hofmeyr, Africa and Science, p. 15.

42 J. C. Smuts, 'The scientific world-picture of to-day', Science, 74 (1931), p. 301; New York Times, 24 Sept. 1931. 
wholes is discernible, not merely in connexion with life, but also, though to a less developed extent, in the inorganic world' (he did, however, express doubts about Smuts's 'treatment of personality'). 43

Whatever its merits as philosophy, Smuts's ideas did a great deal to influence the development of modern ecological thought, not least through the idea of holistic interconnectivity. 44 It is also worth noting that Smuts's interest in spiritual as well as organic evolution meant that he did not commit himself to the hard forms of determinism which were so characteristic of racial theory and eugenics at the time.

In political terms, holism revealed how the nationality of a small, independent, country like South Africa might find more capacious expression in the larger identity of the Commonwealth. In respect of domestic white politics, the metaphor amounted to a belief in the need to transcend white ethnic differences and to strive for an inclusive nationalism that laid more emphasis on place than race, in other words on patriotism rather than nativist nationalism. The political slogan of 'South Africanism' that defined Smuts's vision stands in contrast to that of his long-term political rival, J. B. M. Hertzog, who campaigned in favour of 'South Africa First'. An influential Stellenbosch University theoretical physicist, A. C. Cilliers, who had studied in Germany under Heisenberg, was quick to see the political danger from an Afrikaner nationalist perspective. In Cilliers's view, Smutsian holism implied subsuming South Africa within the British empire. 45

Both slogans gave house room in the polis to whites alone. This was a time when the racial question was code for conflict between English- and Afrikaans-speakers; race was thus seen as distinct from the colour question (which formed the central plank of Hertzog's 1929 'Black Peril' general election campaign). Smuts was a more high-minded kind of segregationist. In 1929, he delivered the Rhodes lectures in Oxford, proposing segregation as a compromise between the concept of permanent racial inferiority (the view of slavery) and the principle of equality and fraternity (which he identified as arising out of the French Revolution). Nothing could be worse, said Smuts, than designing a policy that would 'de-Africanize the African and turn him either into a beast of the field or into a pseudo-European' ${ }^{4}{ }^{6}$ In place of biological determinism, Smuts became absorbed by theories of cultural relativism

43 J. S. Haldane, The sciences and philosophy. Gifford Lectures, University of Glasgow I927 and 1928 (London [1929]), pp. $13^{6-7 .}$

44 P. Anker, Imperial ecology: environmental order in the British empire, I 895-1945 (Cambridge, MA, 2001), ch. 2; S. Pooley, Burning Table Mountain: an environmental history of fire on the Cape Peninsula (Cape Town, 2015 ), pp. $5^{\mathrm{O}-1}, 64$.

45 J. J. Broodryk, 'Stellenbosse Academici en die Politieke Problematik in Suid Afrika, 19341948' (MA thesis, Stellenbosch, 1991), pp. $15^{-17}$.

$4^{6}$ J. C. Smuts, Africa and some world problems (Oxford, 1930), pp. 76-7; cf. Darwin to J. D. Hooker, 22 July [ 1879 ], Darwin Correspondence Project, Letter no. 12167 , <www.darwinproject.ac.uk/DCP-LETT-1 $2167>$. 
drawn from British social anthropology as well as the practice of indirect rule in colonial Africa.

Smuts's great intellectual gift was as a synthesizer of knowledge. His reflections on humanity and human evolution drew not only from social anthropology but also from physical anthropology, palaeoanthropology, and conceptions of geological deep time - all of which were wrapped up in layers of Christian metaphysics, vestiges of vitalism, elements of evolutionism, and spiced with an early reading of Einsteinian relativity and 'space-time' theory.

In the Second World War, Smuts narrowly succeeded in bringing South Africa into the war on the side of the Allies. As in the Great War, he was a key member of the imperial war cabinet and he became a trusted adviser to Churchill. As well as giving house-room to the displaced Greek royal family, Smuts gave shelter to the French prehistorian and renowned world expert on rock art, Abbé Breuil, whom he had spirited out of Lisbon to work on South Africa's new Archaeological Survey. 47

In December 1942, just months after the decisive battle of El Alamein in North Africa, Smuts invited Breuil to Doornkloof, his farm outside Pretoria (Figure 2). Here, he assembled a fine library, entertained foreign dignitaries, and rambled in the veld. Together, Smuts and Breuil discussed the antiquity of humankind. Smuts took the side of those who considered that the origins of humankind in Africa dated back to the Pliocene. Breuil was not convinced. Yet, there was evidently concordance between Smuts and the Abbé in their spiritual understanding of mankind's place in the cosmos. Both were committed to a view of evolutionism that was consistent with Christian theology. $4^{8}$

In 1943, Breuil delivered an address to the South African Association for Science on 'science and theology' in which he highlighted a long tradition of Catholic prehistorians (of which he was the leading representative) and referred to a private audience he had had with Pope Pius XI. Breuil's immodest conclusion was that 'The science of fossil Man apparently does not get on so badly with the Christian Church and its representatives.' 49 The mystical communion and networks of patronage that drew the French prehistorian to the South African politician was amply reflected in the foreword that Smuts wrote to Breuil's book, Beyond the bounds of history (1949):

For me at least there is a very heartening message in prehistory. On that larger, truer time-scale we see a deeper meaning of our story than that which history conveys to

47 S. Dubow, 'Henri Breuil and the imagination of prehistory: "mixing up rubble, trouble and stratification"', in A. Delmas and P. de la Pēna, eds., Towards a history of archaeology from South Africa, South African Archaeological Society Goodwin Series, 12 (Cape Town, 2019), pp. $31-43$.

${ }^{8}$ Breuil's views on God, the cosmos, evolution, and the force of psychic energy (written during his time in South Africa) closely resemble Smutsian philosophy in its essentials. See e.g. 'Science and faith now in sympathy, says Abbe Breuil', Rand Daily Mail, 29 June 1943.

49 H. Breuil, 'Science and theology: 1860-1940', South African Journal of Science, 31 (1943), pp. 348,349 . 


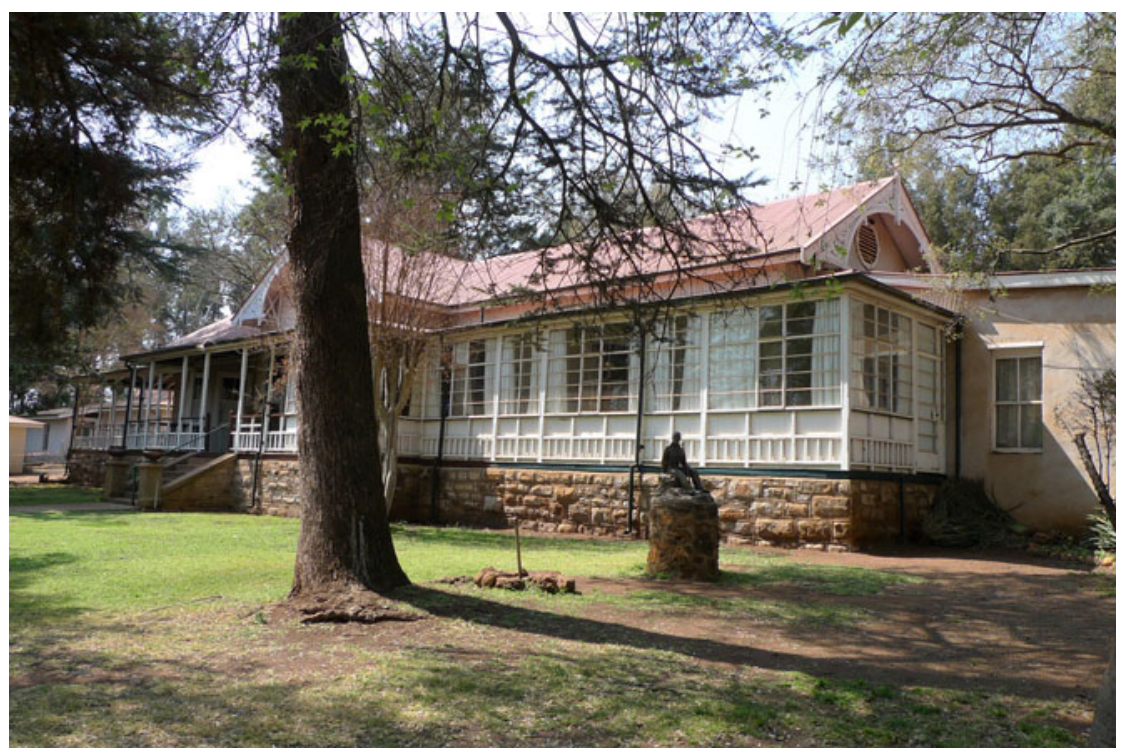

Fig. 2. Doornkloof, Jan Smuts's residence at Irene outside of Pretoria. The house was originally used as a British officers' mess in India then transported to South Africa where it formed part of Lord Kitchener's headquarters during the Boer War. Smuts moved the wood and iron building to his farm at Irene, and entertained countless international celebrities and intellectuals here. Doornkloof also housed his extensive personal library.

us. On the time-scale of history which covers only a few thousand years we do not see much essential progress. Institutions change, forms of human life and existence change, but man himself remains much the same... To see the true picture we have to take a larger time-scale. We have to call in the witness of prehistory. And then the answer is no longer in doubt. The progress physically, mentally and socially is almost beyond belief. $5^{\circ}$

Smuts and Breuil shared a spiritually informed paternalist view that the Bushmen of South Africa evinced qualities of the human spirit which enlarged understandings of humanity; yet, neither credited Bushmen as being fully human in the modern sense. Breuil went to great efforts, for example, to show that the astonishing central frieze in cave paintings he studied in Namibia, the so-called White Lady of the Brandberg, depicted a beautiful Mediterranean girl from the court of Knossos. The great European prehistorian and Jesuit priest had evidently failed to spot or to accept that she was neither white, nor female. $5^{1}$

Racism is not one thing. Smuts, the elusive metaphysican of human evolution and 'personhood', steered clear of crude eugenics. He managed, over a long

$5^{\circ}$ J. C. Smuts, 'Foreword', to H. Breuil, Beyond the bounds of history (London, 1949), pp. 8-9.

$5^{1}$ Dubow, 'Henri Breuil and the imagination of prehistory', pp. 34-5. 
political career, to avoid unnecessarily stirring up racial passions (confrontations with Gandhi over Asian immigration and rights, and occasional inadvertent insults notwithstanding).$^{2}$ His habitual gradualism and reluctant meliorism in respect of race relations was underpinned by a deep-time perspective that encouraged him to defer matters like equal political citizenship to the distant future. Shaped by his upbringing on the old-world Dutch and Huguenot wine-growing estates of the Western Cape, where slavery had transmuted into semi-feudal labour based on deference, Smuts believed in the existence of persistent cultural and spiritual differences. He was thus a profound intellectual racialist, to revive an older sociological term, rather than a racial populistwhich also helps to explain why he could be a segregationist and yet an opponent of apartheid.

\section{I}

One consolation for Smuts's surprising loss of office in 1948 was his election as chancellor of Cambridge University. This was recognition of his military support of Britain in two world wars and his role as an international statesman too. Just as importantly, it was a self-congratulatory pat on the back by a British establishment and populace who were spell-bound by the romantic story of Boer guerrilla fighter turned imperial statesman and international peacemaker. At Smuts's inauguration in June 1948, Cambridge's vice-chancellor spoke about how defeat could be more ennobling than victory. He called Smuts a 'philosopherking' who was about to become 'the dikaios, the just man made prefect'.53 Enthusiastic crowds followed the procession through the streets of Cambridge.

The Smuts Memorial Fund launched a public appeal in 1951. Led by archimperialist, Leo Amery, with the support of Churchill and Attlee, the Fund rapidly met its financial target of $£_{1} 5^{\mathrm{O}}$,ooo through subscriptions and covenants. 54 Conversely, Smuts was a highly controversial figure in South Africa. He was despised by Afrikaner nationalists as the 'handyman' of imperialism and capitalism; regarded by African nationalists as yet another white segregationist; and criticized by many white liberals and radicals for having reneged on wartime promises to bring fundamental social and political reforms.

By contrast, in the field of science and technology, the South African warfare state made major advances in the country's research base. In the 193 os and 1940s, Hendrik van der Bijl, a talented American-trained research physicist and a key ally of Smuts, was responsible for national electricity production,

\footnotetext{
$5^{2}$ Another exception was the speech he gave at Howard University in 1930. See Robert Edgar and Myra Ann Houser, "The most patient of animals, next to the ass": Jan Smuts, Howard University, and African American leadership, 1930', Safundi, 18 (2017), pp. 29-51.

53 Cambridge University Archives/CUR 49.76b, 'Proceedings on Thursday, June 10, on the occasion of the installation of the chancellor'.

54 See correspondence and memoranda in Cambridge University Archives, UA FB 768 box $115^{8}$.
} 
social and economic planning, as well as wartime industrial production. Towards the end of the war, Smuts invited Basil Schonland, an accomplished Cambridge-educated physicist, to create the Council for Scientific and Industrial Research (CSIR), based on British and Commonwealth models. During the war, Schonland secretly pioneered the development of radar (from first principles) to defend South Africa from coastal invasion, and he also served as General Montgomery's scientific adviser. Disillusioned by the prospects of science and politics in apartheid South Africa, Schonland left to join the British Atomic Energy Research Establishment at Harwell in 1954, which he went on to lead.

Schonland's withdrawal from the CSIR, the sudden death of van der Bijl in 1948 , and Smuts's loss of the apartheid election in the same year, portended the end of the Smutsian developmental state with its international links to the Commonwealth. Many anglophile liberals saw the new apartheid prime minister, Dr Malan, a dour Dutch reformed minister, as insular and hostile to progress. Key liberal-minded scientists and doctors left the country. Yet, there were many areas of science and technology that prospered during the autarky of the apartheid years.

From the start, the apartheid government worked effectively to maintain international links in fields like conservation, agriculture, and geophysics. Government commitment to self-sufficiency led to the creation, by the mid-195os, of a strategic oil-from-coal industry based on the German Fischer-Tropsch chemical process. From the 196os, resources were ploughed into large dams and hydro-electric schemes. The CSIR provided research support for a wide range of industries and products, while spin-off companies countered the arms boycott by developing capacity in aeronautics, heavy armour, and artillery. Most conspicuously, nuclear science benefited from the country's plentiful supplies of uranium and its fear of communism. Primed by techno-nationalist pride, this led to the country producing a not-so-secret nuclear bomb by the early 1980 os.

Theological and political conservatism constrained government support of archaeology and palaeontology. The Transvaal Museum in Pretoria came under political pressure when it mounted exhibitions detailing the history of human evolution in South Africa in $195^{2}$ and again in 1963. The advent of archaeological interest in the Bantu iron age, which flourished on liberal English-speaking campuses from the 1960 , proved disturbing to white nationalist master narratives that expressly linked the spread of Christian civilization and progress to European settlement and the vanquishing of hostile African barbarians. The University of Pretoria actually suppressed or shelved its own archaeological research into Mapungupwe, an extensive and prosperous African medieval pre-colonial kingdom set at the confluence of the Limpopo and Shase rivers. 55 Like the associated and archaeological ruins of Great

55 See e.g. Shadreck Chirikure et al., Mapungupwe reconsidered: a living legacy: exploring beyond the rise and decline of the Mapungubwe state (Johannesburg, 2015). 
Zimbabwe, white supremacists were disinclined to believe that these culturally rich kingdoms were the products of indigenous African endeavour.

\section{I I}

Reference has been made already to Jan Smuts's enthusiasm for developing a South African Antarctic presence, arising out of his interests in Gondwanaland and palaeobotany. In the 1920s, a number of Australian and British experts suggested that South Africa might extend its sovereign rights in the Antarctic so as to participate in the establishment of weather stations and extend the range of its fisheries. The arrival, in 1937, of a new physics professor at the University of Cape Town, Reginald James, helped to fire up public interest; James had been a member of Shackleton's Endurance expedition and he gave riveting public lectures about the harrowing fight to survive on ice-floes. $5^{6}$

Cape Town-based geologist, Alex du Toit, was deeply interested in Antarctic research because the southernmost continent was crucial to his theories of continental drift. From 1943 until 1947, du Toit worked to develop detailed plans with Natal University geomorphologist, L. C. King, and in association with the South African Geological Society, to mount a polar expedition. This would involve research programmes in meteorology, geophysics, geology, and oceanography. Frank Debenham of the Scott Polar Institute in Cambridge gave support to the idea. In 1944, a deputation lobbied Smuts who suggested, in non-committal terms, a 'Southern Polar Year' of collaborative international science following the end of the war. 57

Du Toit was himself deeply interested in palaeobotany and palaeogeography. After his death in 1948, Edna Plumstead, a Wits University-trained geologist and a notable representative of a century-old tradition of women botanists in South Africa - produced important work on fossil Glossopteris flora in Antarctica. Her innovative studies provided confirmatory evidence about Gondwanaland and the theory of continental drift. In support of these claims, Plumstead generously cited Smuts's 'prophetic' 1925 presidential address as well as the 'inspiration' of Alex du Toit, who had long been accumulating tell-tale evidence of Glossopteris ferns in corresponding continental masses of the southern hemisphere. $5^{8}$

$5^{6}$ For a good discussion of this early period of Antarctic interest, see L.-M. van der Watt and S. Swart, 'Falling off the map: South Africa, Antarctica and empire, c. 1919-1959', Journal of Imperial and Commonwealth History, 43 (2015), pp. 267-91.

57 For details, see correspondence in A. L. du Toit papers, file J.1, 'Antarctic Expedition 1944-7', e.g. 'The Geological Society of South Africa: memorandum upon a proposed "international polar year" in the southern hemisphere', Johannesburg, 3o Jan. 1946.

$5^{8}$ H. R. Frankel, The continental drift controversy, I: Wegener and the early debate (Cambridge, 2012 ), p. 283; Edna P. Plumstead, Fossil floras of Antarctica: Trans-Antarctic Expedition 1955I958, Scientific Reports, 9 (London, 1962), pp. 126-7; Edna P. Plumstead, Three thousand 
Plumstead's work was significantly advanced by her invitation to describe fossil plants collected during the $1955^{-8}$ Commonwealth Trans-Antarctic Expedition led by Vivian Fuchs. One of those selected to join the Fuchs's party was a young Afrikaner meteorologist, Hannes la Grange, who thereby became the first South African to reach the South Pole. He was awarded a polar medal by Queen Elizabeth and, in 1964, became the first recipient of the South African Antarctic Medal. South Africa's presence in the Southern Ocean dated back to 1947-8 when a naval detachment took occupation of Prince Edward and Marion islands with a meteorological station established at 'Transvaal Cove'. In addition to monitoring weather patterns, fears of encirclement by the Soviets, who were renewing their Antarctic ambitions, was an important motivation: in the Cold War, apartheid South Africa attempted to offset international criticisms by situating itself as a key ally of the West.

In 1959, la Grange was appointed to lead a South African Antarctic Expedition, spurred by apartheid prime minister Verwoerd who is said to have telephoned him to say the country required his services. Verwoerd's son, Wilhelm, an academic geologist and expert on Marion and Gough islands, made a strong case for South Africa's scientific involvement in Antarctica: it was a terrain where scientific achievement and national prestige could be combined with exploration in the spirit of Shackleton, Amundsen, and Scott.59

A key aspect of the Antarctic programme was the establishment of a permanent South African base, replacing the Norwegian presence on Queen Maud Land. The process of laying scientific and strategic claim to the Antarctic (South Africa served as a founding member of the Antarctic Treaty System) was presented as a South African and, more particularly, an Afrikaner triumph. La Grange and his team were honoured with newly minted Antarctica medals on their return home to Cape Town in 1962; English-speaking South African newspapers featured jokey cartoons featuring black and white penguins on an otherwise pristine white landscape. The exploits of these intrepid pipe-smoking frontiersmen, with their beards and masculine bonhomie, illustrate well Klaus Dodds's point that the Antarctic serves as 'a kind of fantasy space for white European men, in particular, to perform "firsts" and record their "achievements" in the name of national and individual power'. ${ }^{60}$

The apartheid state also showed growing interest in astronomy. As late as the 196os, the country's two leading observatories - the Royal Observatory and the Radcliffe Observatory-were British-run and controlled. European and

\footnotetext{
million years of plant life in Africa, Alex L. du Toit Memorial Lectures no. 1 1, Annex to vol. 72 (1969), p. 1 .

59 W. J. Verwoerd, 'Waarom Navorsing in Antarktika?', Tegnikon, 15 (1967), p. 102.

6o Klaus Dodds, The Antarctic: a very short introduction (Oxford, 2012), pp. 41, 63. For contemporary accounts of South Africa's Antarctic story, see the South African Weather Bureau's monthly periodical, Nuusbrief.Newsletter, published in Pretoria from 1949.
} 
American universities operated their own telescopes around Johannesburg and Bloemfontein. Yet, by the early 1960 , the British were considering winding down their operations and moving their telescopes to Australia. Even the future of the Royal Observatory was in doubt.

There were undoubted scientific successes, such as the announcement in $195^{2}$ by Cambridge-educated Radcliffe Observer, David Thackeray, that the universe was double the size of current estimates: evidence of RR Lyrae variables in the Magellanic Clouds, visible from the southern hemisphere, resolved a puzzle whereby the earth seemed to be older than the universe itself (Figure 3). But the broader picture suggests that for much of the twentieth century, astronomy in South Africa was mostly a routine matter of hosting observatories for the benefit of overseas universities who sought pollution-free portals into the southern skies. Anti-apartheid sentiment prompted the Swedes to abandon their involvement in the Boyden telescope in 1966, and the Americans to terminate their 'deep space' tracking programme at the Hartebeesthoek radio telescope in 1974. This facility was used to track NASA space missions and so fell under the shadow of the growing security apparatus. The CSIR, led by Meiring Naudé, was discomfited by the lack of national control and overall direction of astronomy and now saw an opportunity to exercise more decisive leadership. ${ }^{61}$

It was at this nadir in South African astronomy that the government intervened and proposed consolidating the Cape Town, Pretoria, and Johannesburg observatories on a site just outside of Sutherland in the Karoo. The CSIR referred to the remote village or dorp as 'a new name in the world of astronomy' where 'the science of the stars will meet the science of the earth'. The Karoo Supergroup is an ancient geological assemblage that has proved key to understanding the formation of Gondwanaland at the end of the Carboniferous period. It has long been associated with 'mammal-like reptiles' or therapsids, first identified by the multi-talented self-taught Scottish geologist and road-maker, Andrew Geddes Bain. His discovery of Dicynodon aroused the interest of T. H. Huxley and Richard Owen who described the bidental creature in 1845 and gave the species its name. These $25^{\mathrm{O}-m i l l i o n-y e a r-o l d ~ f o s s i l s ~ a r e ~ n o w ~ s e e n ~ a s ~ e v i d e n c e ~ o f ~ g l o b a l ~ f a u n a l ~}$ and floral interchange and so serve as further evidence of continental drift. More recently, fossil coelacanth fishes have been discovered in the region. ${ }^{62}$

On the occasion of the opening of the South African Astronomical Observatory at Sutherland in 1973, a smiling Margaret Thatcher, British

${ }^{61}$ This paragraph draws on my '200 years of astronomy in South Africa'.

62 Scientiae, 14 (1973), p. 6; Bruce Rubidge, '27 th du Toit Memorial Lecture: reuniting lost continents: fossil reptiles from the ancient Karoo and their wanderlust', South African Journal of Geology, 208 (2005), p. 137; W. K. Hancock, Smuts, I: The sanguine years, I870-I9I9 (Cambridge, 1962), pp. 397-8. 


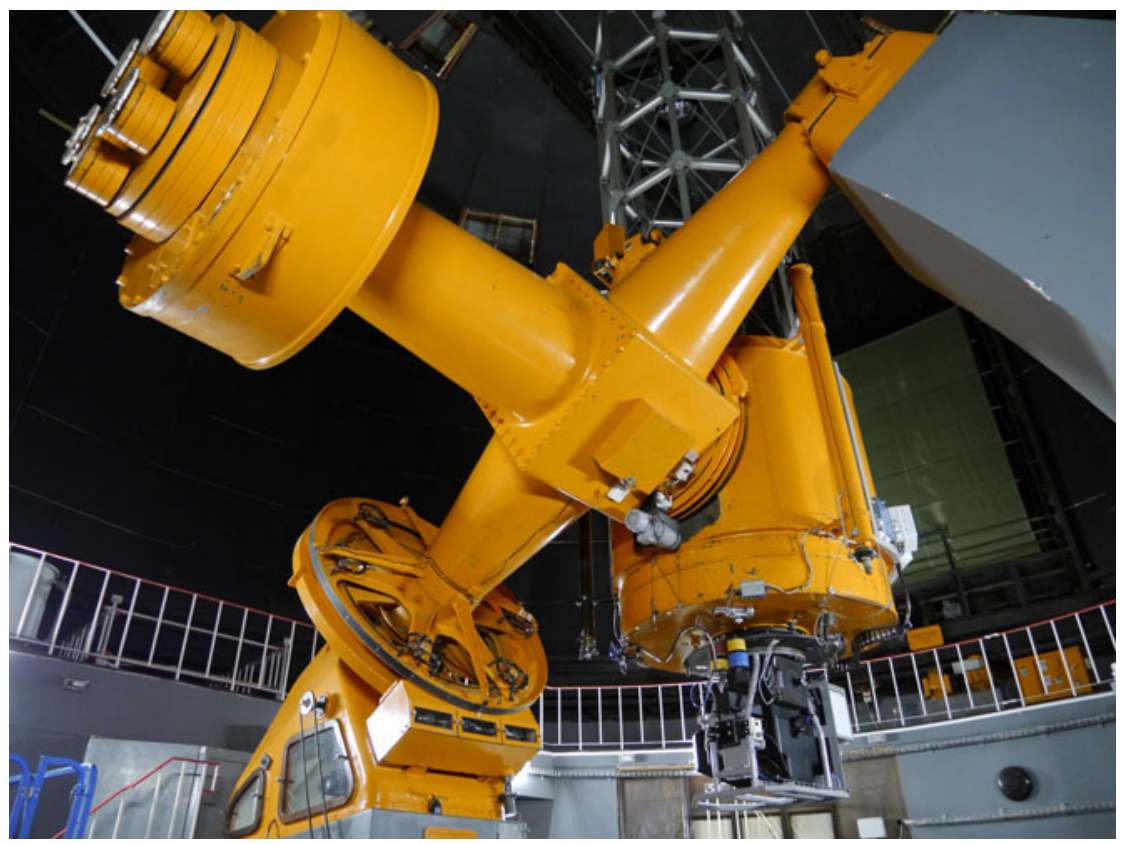

Fig. 3. Interior of Radcliffe 74-inch telescope, SAAO, Sutherland, Cape. The Radcliffe Observatory, founded in the $177 \mathrm{Os}$, moved operations to Pretoria after 1934 where this telescope was constructed by Howard Grubb, Parsons and Co., becoming operational from 1948. It was then the largest optical telescope in the southern hemisphere. The telescope was moved to Sutherland and recommenced observations in 1976 .

secretary of state for science and technology, sat alongside a gruff South African prime minister John Vorster, who presided over a ceremony attended by 400 scientific and diplomatic dignitaries. Thirty years after his release from internment by Smuts as a Nazi sympathizer, Vorster now stressed the necessity for international and bilateral co-operation in efforts to further knowledge of the southern skies. He was at the time keen to break South Africa's isolation and to establish a diplomatic presence in Africa. The British sought to maintain their presence in South African astronomy while paring down expenditure. Thatcher, who drew praise for lending 'elegance and distinction' to the occasion, declined to be drawn into discussion about the precise nature of the bilateral agreement, which preserved a third of the observing time at Sutherland to be made available to British universities. ${ }^{63}$ The rumour doing the rounds at the time was that she was also seeking to sell Concorde to South Africa.

63 D. G. Kingwill, The CSIR, the first 40 years (Pretoria, 1990), p. 188; Rand Daily Mail, 15 Mar. 1973, 16 Mar. 1973; Sutherland Observing Station-SAAO-formal opening 15th March 1973, souvenir brochure (Pretoria, CSIR, 1973), p. ii. 


\section{I I I}

Many of South Africa's key contributions to global science have taken advantage of the country's geographic position in the southern hemisphere. Astronomy, Antarctic research, and palaeoanthropology are all pathways into deep time and three-dimensional space. These were identified as important in Jan Smuts's 'South Africanist' vision of scientific possibility; they were pursued with different emphasis through the apartheid era, and they became areas of niche advantage in the post-apartheid era, rekindled by the country's 'miraculous' political transition in the 1990 s that heralded its re-entry into global science.

There are some striking parallels between these moments. As Nathan Schlanger puts it, for all the differences between their affinities and contexts, there are 'remarkable affinities in tone and in worldview', not least in their 'detailed recourse to scientific claims and authority', that invite comparisons between philosopher-statesmen Smuts and Mbeki. ${ }^{6} 4$ Smuts's outward-looking patriotism was focused on the Commonwealth. In the spirit of what I have elsewhere termed 'acquired indigeneity', he sought to decolonize science by South Africanizing it under white leadership, while offering his country as a global laboratory for the study of race. Smuts and his supporters also mapped out a sub-imperial role for science as the vector for further expansion and influence in colonial Africa.

Post-apartheid South Africa has placed a very different Africanist emphasis on indigenous knowledge, albeit one that continues to stress its regional leadership and distinct scientific advantages. The Southern African Large Telescope and the SKA (which has a number of potential African partners) provides one example. The country's revived Antarctic presence takes pride in the country's contribution to global research into biodiversity and climate change, as well as the fact that it is the only African country with a presence in the Southern Ocean. Palaeoanthropology stresses Africa's and South Africa's unique contribution as the progenitor of humankind.

That South Africa is able to play a role in global science as an African nation has both an external and an internal dimension, namely, the complicated relationship between indigenous or local and universal or global knowledge. The promoters of 'big sciences' such as astronomy, palaeoanthropology, and Antarctic research utilize 'rainbowist' visions of multi-racial co-existence and sharing. But these assumptions are under increasing strain a generation after the end of apartheid. Mbeki's African renaissance was in part a challenge to 'Western' science, and some in the 'decolonialization' movement have science in their sights. Mandela's wonderment at Mqayhi's division of the southern stars between Europeans and Africans thus acquires fresh resonance.

\footnotetext{
${ }^{64}$ Nathan Schlanger, 'Recomposing identities: prehistory and human origins from Jan Christiaan Smuts to Thabo Mbeki', in Delmas and de la Pēna, eds., Towards a history of archaeology, p. 25 .
} 
In order to comprehend the long and complicated history of science in twentieth-century South Africa we need to pay close attention to the politics of knowledge. The optimistic moment of the 1990s, when the world welcomed South Africa back to the international community, was also a time when postcolonial theory encountered unfettered globalization. These were also the early, exciting years of the World Wide Web and the prospect of free access to the democracy of the intellectual commons. Linking these processes were new approaches to the study of knowledge and a questioning of the central place of imperial metropoles. Although different political objectives and inflections were in play, a common free-flowing metaphorical repertoire was generated in the coinage of webs, circulation, interchange, nodes, co-mutuality, hybridity, cosmopolitanism, and so on. ${ }^{6} 5$ Such conceptions of co-production helped to smooth South Africa's passage back into global science. Today, however, global intellectual historians are far more aware of the blockages, impediments, and persistent inequities in relations of power and influence that govern the exchange and distribution of ideas.

Asymmetric power relations characterize South Africa's long engagement with global science-and are also more important than interpretations of history which privilege race and political economy to the exclusion of ideas. Almost entirely overlooked is the question of how mid-level states fit into the overall architecture of global geopolitics. Part of the fascination of South Africa for the outside world is that it was a sub-regional power that was too big to ignore but not significant enough to pose a threat to anyone beyond its regional neighbourhood. The complexity of the country's peopling, its multi-layered experience of European colonization, as well as the system of segregation and apartheid that made it an international pariah for the last half of the twentieth century, makes it eminently suitable as a localized site for global history.

Historians of extra-European science have long experimented with models of knowledge diffusion. The tendency has been to move away from the idea of knowledge radiating out like the spokes of a wheel from northern centres. There is now much greater emphasis on how the so-called periphery can act disproportionately upon metropolitan cores. Jean and John Comaroff posit the concept of 'theory from the South', claiming that 'modernity was, almost from the start, a North-South collaboration - indeed, a world-historical production - albeit a sharply asymmetrical one'. ${ }^{66}$ Roy MacLeod's conception of the 'moving metropolis' still has value, more especially when we bear in mind that this phrase was borrowed from the great Australian, and one might add

\footnotetext{
65 Post-colonial theory was of course very concerned with the unequal politics of representation, but one consequence of analysing stereotypes of the 'other' was to pay insufficient attention to their differences as well as their modes of diffusion and circulation.

66 Jean and John Comaroff, 'Theory from the south: or, how Euro-America is evolving toward Africa', Anthropological Forum, 22 (2012), p. 116.
} 
greater British, historian, Keith Hancock. Tony Smith's proposal of a 'pericentricity', in the case of the global Cold War, might also be of use to historians of global intellectual history and science. ${ }^{67}$ There is considerable interest, too, amongst scholars in the humanities, in South-South connections which do not interface directly with northern entrepots.

Clearly, more attention needs to be paid to the role of national formations in science as a transnational activity. Daniela Bleichmar's study of botany and visual cultures in the Spanish empire is suggestive of how knowledge generated in Latin America worked not only to the benefit of Madrid but also positioned the New World to generate scientific self-knowledge and 'creole patriotism'. Sujit Sivasundaram's conception of 'Islanding' in the case of Sri-Lanka is a suggestive reformulation, not least because it shifts the centre of gravity away from the British empire to the Indian and Pacific oceans. Australians, including Alison Bashford and Warwick Anderson, are exploring southern hemispheric connections that go beyond British Dominion relations. Elise Burton's work on the medical study of genetic diseases from the $195^{\text {os demonstrates how }}$ scientists in middle eastern countries like Turkey, Lebanon, Iran, and Israel developed local centres of research, both because they had closer access to blood samples than established centres in North America and Britain, and also because they were motivated to rethink national ethnic and racial categories around 'Arabness' and 'Jewishness'. Crucially, such assumptions entailed the capacity and the will to replicate colonial-type relationships between dominant and subordinate groups within or beyond their own spheres of influence. ${ }^{68}$

All this suggests a need to pay greater attention to the position of middleranking regional powers, about which there is surprisingly little of a theoretical nature in politics and international relations - as well as in science. I refer, here, to countries that exhibit ties of historic colonial dependence but also manifest aspects of genuine independence and assertiveness in ways that complicate the binary division between colonial and indigenous. Societies such as these have been able to create viable, self-sustaining infrastructures and the means to become semi-autonomous centres of calculation; their ambitions and resources are not adequately captured by the bland status of 'developing nations'.

Some of these middle powers are treated as threats or pariahs. South Africa was a twentieth-century example, Iran and Israel provide compelling contemporary instances. India, with its authoritarian tilt towards science in the

\footnotetext{
67 Tony Smith, 'New bottles for new wine: a pericentric framework for the study of the Cold War', Diplomatic History, 24 (200o), pp. 567-91.

68 Sujit Sivasundaram, Islanded: Britain, Sri Lanka, and the bounds of an Indian Ocean Colony (Chicago, IL, 2013); Elise K. Burton, "Essential collaborators": locating middle eastern geneticists in the global scientific infrastructure, 1950s-1970s', Comparative Studies in Society and History, 6o (2018), pp. 119-49; idem, 'Red crescents: race, genetics and sickle cell disease in the middle east', Isis, 110 (2019), pp. 250-69; Daniela Bleichmar, 'The imperial visual archive: images, evidence, and knowledge in the early modern Hispanic world', Colonial Latin American Review, 24 (2015), pp. 236-66.
} 
service of Hindutva, is replicating such tendencies. ${ }^{69}$ Insufficiently understood are the ways in which such regional centres fit within national as well as global priorities as well as how the production of scientific knowledge adopts and adapts institutionally, culturally, and politically. Science, perhaps more than any other intellectual activity, has been key to South African international purchase and presence. But its importance is apt to be overlooked, partly because governments and researchers alike have been successful in presenting science and technology as a prestigious vector of beneficial development. Yet, far from being politically neutral, science has long served as an ancilliary to government power and geopolitical influence.

69 James Delbourgo, 'The knowing world: a new global history of science', History of Science, 57 (2019), pp. $375^{-6 .}$ 